\title{
Phase 1b Study of Trebananib Plus Paclitaxel and Trastuzumab in Patients With HER2-Positive Locally Recurrent or Metastatic Breast Cancer
}

\author{
Peter A. Kaufman, ${ }^{1}$ Hans Wildiers, ${ }^{2}$ Gilles Freyer, ${ }^{3}$ Margaret Kemeny, ${ }^{4}$ \\ Anthony Gonçalves, ${ }^{5}$ Guy Jerusalem, ${ }^{6}$ Alison Stopeck, ${ }^{7}$ Nandagopal Vrindavanam, ${ }^{8}$ \\ Florence Dalenc, ${ }^{9}$ Nuwan Nanayakkara, ${ }^{10}$ Benjamin Wu, ${ }^{11}$ Cheryl A. Pickett ${ }^{12}$
}

\section{Abstract}

Given the potential interactions between human epidermal growth factor receptor 2 (HER2) signaling and angiogenesis, we investigated the angiopoietin (Ang) 1/Ang2 inhibitor trebananib plus trastuzumab and paclitaxel in HER2-positive breast cancer. Forty women received trebananib (10 or $30 \mathrm{mg} / \mathrm{kg}$ ) plus trastuzumab and paclitaxel. The combination demonstrated acceptable toxicity and antitumor response in HER2-positive locally recurrent/metastatic breast cancer.

Introduction: Trebananib, a peptide-Fc fusion protein, blocks angiogenesis by inhibiting binding of angiopoietin-1/2 to the receptor tyrosine kinase Tie2. Trebananib plus trastuzumab and paclitaxel was evaluated in human epidermal growth factor receptor 2-positive breast cancer in an open-label phase $1 \mathrm{~b}$ clinical study. Patients and Methods: Women with human epidermal growth factor receptor 2-positive breast cancer received weekly paclitaxel $\left(80 \mathrm{mg} / \mathrm{m}^{2}\right)$, trastuzumab $\left(8 \mathrm{mg} / \mathrm{m}^{2}\right.$ then $6 \mathrm{mg} / \mathrm{kg}$ every 3 weeks), and intravenous trebananib ( $10 \mathrm{mg} / \mathrm{kg}$ or $30 \mathrm{mg} / \mathrm{kg}$ weekly) beginning week 2 . The primary end point was the incidence of dose-limiting toxicities. Secondary end points included incidence of adverse events (AEs), pharmacokinetics, and tumor response (objective response and duration of response). Results: Forty women were enrolled; 2 experienced dose-limiting toxicities (grade 3 ocular transient ischemic attack [10 mg/kg cohort] and grade 3 elevation in $\gamma$-glutamyl transferase [30 mg/kg cohort]). The most common treatment-emergent AEs were peripheral edema $(n=28)$, diarrhea $(n=27)$, alopecia $(n=26)$, fatigue $(n=24)$, and nausea $(n=24)$. Maximum observed concentration and area under the concentration-time curve increased proportionally with the trebananib dose. Objective response was confirmed in 31 patients. In the $10 \mathrm{mg} / \mathrm{kg}$ cohort, 16 patients $(80 \%)$ experienced partial response, and none experienced complete response. In the $30 \mathrm{mg} / \mathrm{kg}$ cohort, 12 patients $(71 \%)$ experienced partial response and $3(18 \%)$ experienced complete response. Median (95\% confidence interval) duration of response in the 10 and $30 \mathrm{mg} / \mathrm{kg}$ cohorts was 12.6 (4.3-20.2) and 16.6 (8.2-not estimable) months, respectively. Conclusion: This phase $1 \mathrm{~b}$ study showed that trebananib was tolerated with manageable AEs at a dose up to $30 \mathrm{mg} / \mathrm{kg}$ weekly. Trebananib demonstrated anticancer activity, as indicated by objective response and duration of response.

Clinical Breast Cancer, Vol. ஐ, No. a, - - (c) 2018 Published by Elsevier Inc.

Keywords: AMG 386, Angiogenesis, Angiopoietin, HER2 positive

\footnotetext{
${ }^{1}$ Norris Cotton Cancer Center at Dartmouth-Hitchcock Medical Center, Lebanon, $\mathrm{NH}$

${ }^{2}$ KU Leuven and Department of General Medical Oncology, University Hospitals Leuven, Leuven, Belgium

${ }^{3}$ Medical Oncology, HCL Cancer Institute and Lyon 1 University, Lyon, France ${ }^{4}$ Queens Cancer Center, Queens, NY

${ }^{5}$ Department of Medical Oncology, Institut Paoli-Calmettes, Marseille, France

${ }^{6}$ Department of Medical Oncology, CHU Sart Tilman Liège and Liège University, Liège, Belgium

${ }^{7}$ Division of Hematology/Oncology, Stony Brook Cancer Center, Stony Brook, NY

${ }^{8}$ Department of Clinical Research, Signal Point Clinical Research Center, LLC, Middletown, $\mathrm{OH}$
}

\footnotetext{
${ }^{9}$ Department of Medical Oncology, Institut Claudius Regaud, IUCT-Oncopole, Toulouse, France

${ }^{10}$ Quintiles, San Diego, CA

${ }^{11}$ Department of Medical Sciences

${ }^{12}$ Department of Clinical Development, Amgen Inc, Thousand Oaks, CA

Submitted: Jun 27, 2018; Revised: Sep 21, 2018; Accepted: Sep 29, 2018

Address for correspondence: Peter A. Kaufman, MD, Dartmouth-Hitchcock Medical Center, One Medical Center Drive, Lebanon, NH 03756 E-mail contact: Peter.a.kaufman@dartmouth.edu
} 


\section{Trebananib-Paclitaxel-Trastuzumab in Breast Cancer}

\section{Introduction}

Breast cancer is a multifactorial disease, with development, progression, and metastasis regulated by a variety of pathologic processes and signaling pathways, which include tumor angiogenesis ${ }^{1}$ and activation of human epidermal growth factor receptor (EGFR) pathways. ${ }^{2}$ Human epidermal growth factor receptor 2 (HER2) is a member of the EGFR (also called erbB/HER) family of transmembrane tyrosine kinase receptors, which include EGFR1 (erbB1/HER1), HER2 (erbB2/HER2-neu), HER3 (erbB3), and HER4 (erbB4). These receptors are capable of signal transduction causing activation of the Ras/MAP kinase pathway, the PI3K/Akt pathway, src family kinases, and signal transducer and activator of transcription proteins. In addition, HER2 is capable of signal transduction without ligand activation through homodimerization or heterodimerization with other members of the HER family. ${ }^{3}$ Activation of these pathways promotes cell proliferation, survival, and angiogenesis. ${ }^{3,4}$ Overexpression of HER2 in human tumor cells has been shown to be associated with increased angiogenesis and expression of vascular endothelial growth factor (VEGF). ${ }^{5}$ Trastuzumab, a humanized monoclonal antibody directed against HER2, has been shown to inhibit tumor cell growth and VEGF expression. $^{6}$

The HER2 gene is amplified in approximately $20 \%$ to $25 \%$ of patients with breast cancer, and overexpression of HER2 has been shown to be associated with a clinically aggressive form of the disease, leading to poor patient outcomes and prognosis prior to the development of HER2-targeted therapies. ${ }^{2,7}$ In clinical studies, trastuzumab significantly improved overall survival in patients with metastatic HER2-positive breast cancer when administered in combination with chemotherapy. ${ }^{8-10}$ Consequently, trastuzumab has become a standard-of-care treatment in women with HER2positive metastatic breast cancer. ${ }^{11,12}$ Additional agents acting through HER2 and through interaction with other members of the EGFR/HER family such as lapatinib (a dual HER2 and EGFR inhibitor), pertuzumab (which impairs HER2 dimerization with other HER family members), and trastuzumab emtansine (an antibody-drug conjugate) are more recently introduced in the standard of care ${ }^{13,14}$; others, such as neratinib (which targets EGFR, HER2, and HER4) have also shown activity in HER2-positive breast cancer. ${ }^{15}$ Recent data have demonstrated a meaningful therapeutic impact of pertuzumab, in combination with trastuzumab, both in metastatic breast cancer and early stage disease. ${ }^{14,16}$

Angiogenesis has been shown to play a key role in tumor growth and metastasis in breast cancer. ${ }^{1,17,18}$ Many factors, including VEGF and angiopoietin (Ang) 1 and Ang2 regulate tumor angiogenesis. ${ }^{19,20}$ The angiopoietin axis is distinct from the VEGF pathway, with Ang1 and Ang2 regulating angiogenesis and vascular remodeling by interacting with the tyrosine kinase receptor Tie2. ${ }^{19}$ Ang2 is up-regulated at sites of tumor angiogenesis, ${ }^{21}$ is prevalent in tumors of patients with invasive breast cancer, and is associated with poor survival in breast cancer. ${ }^{22,23}$

There is also evidence that cross talk exists between the HER signaling pathway in breast cancer and angiogenic modulation of tumor vasculature, particularly that signaling by HER2 (and other EGFR/HER family members) regulates expression of several angiogenic factors. As a result, there has been a great deal of interest in dual targeting of HER2 and VEGF, and a number of clinical studies have investigated the combination of the VEGF-A inhibitor bevacizumab with trastuzumab and chemotherapy in patients with HER2-positive breast cancer. ${ }^{24,25}$ Although expression of Ang2 in normal tissues appears to be largely limited to endothelial cells, several studies suggest that Ang2 is expressed by tumor cells, including breast cancer cells. ${ }^{6,26,27}$ Furthermore, HER2 overexpression has been shown to up-regulate Ang2 in breast cancer cell lines, ${ }^{26,27}$ suggesting that HER2 tumors might be particularly susceptible to therapies that target angiopoietins.

Trebananib is a peptide-Fc fusion protein that binds Ang1 and Ang2 and prevents their interaction with the Tie 2 receptor. ${ }^{28}$ This inhibition has been shown to suppress tumor cell growth in preclinical studies, ${ }^{28,29}$ and trebananib has shown antitumor activity in clinical studies when administered alone, ${ }^{30}$ in combination with VEGF inhibitors, ${ }^{31-34}$ or in combination with chemotherapy. ${ }^{35-37}$ Trebananib, in combination with various chemotherapy regimens at doses up to $15 \mathrm{mg} / \mathrm{kg}$ weekly, has demonstrated tolerability and efficacy in large phase 3 trials in ovarian cancer. ${ }^{38-41}$

Given the potential interactions between HER2 signaling, the angiopoietin axis, and other modulators of angiogenesis, we investigated the combination of trebananib, trastuzumab, and paclitaxel in patients with HER2-positive breast cancer in this phase $1 \mathrm{~b}$ study. This is the first published report on the use of an angiopoietin inhibitor, trebananib (AMG 386), in combination with trastuzumab and paclitaxel in patients with HER2-positive metastatic breast cancer. This study also extends upon previous safety data of administering trebananib at doses up to $30 \mathrm{mg} / \mathrm{kg}$ weekly, in combination with paclitaxel.

\section{Patients and Methods Study Design and Eligibility}

This open-label phase $1 \mathrm{~b}$ trial, conducted at 16 centers in North America and Europe, started on March 9, 2009, and was completed on October 15, 2015. The study was designed to evaluate trebananib in 2 groups of patients with metastatic breast cancer: one group consisted of patients receiving trebananib with trastuzumab and paclitaxel in a first-line setting, and the second group consisted of patients receiving trebananib with lapatinib and capecitabine after previously failed trastuzumab in a first-line setting. This article reports results only from the trebananib plus trastuzumab and paclitaxel groups. Patients were enrolled sequentially to 2 dose cohorts of trebananib, 10 and $30 \mathrm{mg} / \mathrm{kg}$ weekly. Only after 20 patients had been enrolled in the $10 \mathrm{mg} / \mathrm{kg}$ weekly trebananib dose cohort were patients enrolled in the $30 \mathrm{mg} / \mathrm{kg}$ weekly trebananib dose cohort. Trial registration: ClinicalTrials.gov, NCT00807859.

For the trebananib plus trastuzumab and paclitaxel cohorts, women $(\geq 18$ years) were eligible if they had a histologically or cytologically confirmed diagnosis of adenocarcinoma of the breast with locally recurrent or metastatic disease; had measurable or nonmeasurable disease per Response Evaluation Criteria in Solid Tumors (RECIST) version 1.0 ${ }^{42}$; had an Eastern Cooperative Oncology Group performance status $\leq 1$; and had not received trastuzumab, lapatinib, or chemotherapy for metastatic or locally recurrent disease (trastuzumab in adjuvant or neoadjuvant therapy was allowed). HER2 positivity was confirmed through fluorescence 
in situ hybridization, chromogenic in situ hybridization, or $3+$ staining by immunohistochemistry. Patients were excluded if they had inflammatory breast cancer; history of arterial or venous thrombosis within 1 year; clinically significant cardiovascular disease within 1 year; bleeding diathesis or clinically significant bleeding within 6 months; central nervous system metastasis; nonhealing wound, ulcer, or fracture; history of interstitial pulmonary disease; uncontrolled hypertension (diastolic blood pressure $>90 \mathrm{~mm} \mathrm{Hg}$ or systolic blood pressure $>140 \mathrm{~mm} \mathrm{Hg}$ ); inadequate hepatic, renal, cardiac, or hematologic function; major surgical procedure within 28 days; open breast biopsy within 14 days; minor surgical procedure/fine-needle aspiration within 7 days; radiation therapy within 14 days; prior radiation therapy, radiofrequency ablation, percutaneous cryotherapy, or hepatic chemoembolization on all sites of disease unless disease progression was documented; peripheral neuropathy grade 2 or higher; chemotherapy within 3 weeks; treatment with a VEGF receptor multikinase inhibitor within 21 days; bevacizumab within 45 days; anticoagulation therapy within 1 week; treatment with immune modulators (eg, systemic cyclosporine or tacrolimus) within 30 days; hormonal agent within 14 days; or treatment with any inhibitor of the angiopoietin pathway. The protocol was approved by each center's independent ethics committee; all patients provided written informed consent.

\section{Study Procedures}

Trebananib, trastuzumab, and paclitaxel were administered by intravenous infusion. Patients received paclitaxel $80 \mathrm{mg} / \mathrm{m}^{2}$ once a week. Trastuzumab was administered at a dose of $8 \mathrm{mg} / \mathrm{m}^{2}$ in week 1 followed by $6 \mathrm{mg} / \mathrm{kg}$ once every 3 weeks. Trebananib 10 or 30 $\mathrm{mg} / \mathrm{kg}$ once a week was administered beginning at week 2 . Initially, 6 patients were administered trebananib $10 \mathrm{mg} / \mathrm{kg}$ once a week and standard $6+3$ dose-limiting toxicity (DLT) enrollment criteria were employed. If $\leq 1$ of 6 or $\leq 2$ of 9 patients experienced a DLT, the expansion phase was initiated; alternatively, if $\geq 3$ of 9 patients had a DLT, lower doses of trebananib could be evaluated. Patients who dropped out during the first 28 days of treatment for reasons other than DLT were replaced. In the expansion phase, additional patients were enrolled for a total of 20 patients at the $10 \mathrm{mg} / \mathrm{kg}$ once a week dose. After all 20 subjects in the $10 \mathrm{mg} / \mathrm{kg}$ once a week expansion phase were enrolled, the $30 \mathrm{mg} / \mathrm{kg}$ once a week cohort was opened following the same $6+3$ enrollment and DLT rules as for the $10 \mathrm{mg} / \mathrm{kg}$ once a week dose. This cohort was also expanded to a total of 20 patients at the $30 \mathrm{mg} / \mathrm{kg}$ once a week dose.

Treatment continued until disease progression, unacceptable toxicity, or withdrawal of consent. Dose modifications for trebananib were not permitted. If trebananib was withheld for $>28$ days or more than twice for treatment-related toxicity, treatment with trebananib was permanently discontinued. Dose modifications were not permitted for trastuzumab. Doses of paclitaxel could be modified based on protocol-specified rules consistent with the prescribing information for each drug.

\section{End Points}

The primary end point was the incidence of adverse events (AEs) and clinical laboratory abnormalities, defined as DLTs, of the trebananib cohorts. Patients who experienced an event before initiation of trebananib were not evaluated for a DLT. DLTs were defined as any grade $\geq 3$ hematologic or nonhematologic toxicities as defined by Common Terminology Criteria for Adverse Events (CTCAE) version 3.0, ${ }^{43}$ with the following modifications: grade 3 infusion reactions lasting $>2$ hours, grade 3 fatigue persisting for $>7$ days, grade 4 diarrhea that persists despite maximum supportive care, grade 3 or 4 nausea/vomiting for $>72$ hours, grade 3 or 4 neutropenia with fever $\left(>38.5^{\circ} \mathrm{C}\right)$, grade 4 neutropenia lasting $>7$ days, grade 4 thrombocytopenia, grade 4 anemia, grade 4 hypertension, or aspartate aminotransferase/alanine aminotransferase $>10 \times$ upper limit of normal. DLTs were evaluated for all patients who received at least 2 doses of trebananib and 1 dose of trastuzumab. The evaluation period for DLTs was 21 days from the first dose of study drug. Secondary end points included incidences of other AEs and clinical laboratory abnormalities not defined as DLTs, pharmacokinetic profiles of trebananib, trastuzumab, and paclitaxel, objective response (OR), duration of response (DOR), change in tumor burden, progression-free survival (PFS), and incidence of anti-trebananib antibodies.

\section{Assessments}

AEs occurring from the start of treatment to 30 days after the last dose were recorded and graded using CTCAE version 3.0. Potential relationship of $\mathrm{AEs}$ to study treatment was assessed by the investigators. In addition to routine physical examinations, vital signs, electrocardiograms, and safety laboratory results, left ventricular ejection fraction was evaluated by multigated acquisition scan or echocardiogram (at baseline, week 9, week 18, then every 18 weeks, and at safety follow-up).

Radiologic imaging (computed tomography or magnetic resonance imaging) of at least the chest, abdomen, and pelvis was done before cycle 1 and every $9 \pm 1$ weeks after the first dose of study treatment until disease progression or the safety follow-up visit. Imaging was evaluated by investigators per RECIST version 1.0. Patients with a partial response or complete response had a confirmatory radiographic evaluation conducted at least 28 days from the initial evaluation of response.

\section{Pharmacokinetics}

Serum samples for evaluation of trebananib and trastuzumab pharmacokinetics were collected from all patients before infusion as well as within 10 minutes after infusion of trebananib, trastuzumab, and paclitaxel on day 1 of weeks 7 and 19 and every $9 \pm 1$ weeks thereafter. Serum samples were also taken 6, 24, 48, 96, and 168 hours after the end of trebananib infusion on day 1 of week 7 , or at $6,24,48,96,168,336$, and 504 hours after the end of trastuzumab infusion on day 1 of week 7 . Plasma samples for evaluation of the pharmacokinetics of paclitaxel were collected before paclitaxel and trebananib/trastuzumab infusion on day 1 of weeks $1,7,19$, 28, 37, and 46 and within 5 minutes after the end of infusion of paclitaxel on day 1 of weeks 1 and 7. Analysis of individual serum trebananib, individual plasma paclitaxel, and individual serum trastuzumab was made by comparing concentrations before treatment (day 1 of week 1) and after treatment (steady state at week 7). The pharmacokinetics of paclitaxel when administered with trastuzumab on day 1 of week 1 (without trebananib) and week 7 (paclitaxel with trastuzumab and trebananib at steady state) were compared. 


\section{Trebananib-Paclitaxel-Trastuzumab in Breast Cancer}

Table 1 Baseline Demographics and Clinical Characteristics

\begin{tabular}{|c|c|c|}
\hline Characteristic & $\begin{array}{c}\text { Trebananib } 10 \mathrm{mg} / \mathrm{kg}+\text { Trastuzumab/ } \\
\text { Paclitaxel }(\mathrm{n}=20)\end{array}$ & $\begin{array}{c}\text { Trebananib } 30 \mathrm{mg} / \mathrm{kg}+\text { Trastuzumab/ } \\
\text { Paclitaxel }(\mathrm{n}=20)\end{array}$ \\
\hline Age (years), median (range) & $54.5(29-76)$ & $51.5(33-74)$ \\
\hline \multicolumn{3}{|l|}{ Race } \\
\hline White & $17(85)$ & $19(95)$ \\
\hline Black/African American & $1(5)$ & 0 \\
\hline Hispanic/Latino & $1(5)$ & $1(5)$ \\
\hline Other & 1 (5) & 0 \\
\hline \multicolumn{3}{|l|}{ ECOG PS } \\
\hline 0 & $11(55)$ & $11(55)$ \\
\hline 1 & $9(45)$ & $9(45)$ \\
\hline 2 & 0 & 0 \\
\hline No. of metastatic sites $\leq 3$ & $17(85)$ & $18(90)$ \\
\hline Time (months) since LR/MBC diagnosis, median (range) & $1.1(0.3-90.1)$ & $1.1(0.1-7.0)$ \\
\hline Prior adjuvant or neoadjuvant chemotherapies & $8(40)$ & $8(40)$ \\
\hline Prior trastuzumab (neoadjuvant setting) & $2(10)$ & $7(35)$ \\
\hline
\end{tabular}

Data are presented as $\mathrm{n}(\%)$ unless otherwise indicated.

Abbreviations: ECOG PS = Eastern Cooperative Oncology Group performance status; LR/MBC = locally recurrent or metastatic breast cancer.

\section{Immunogenicity}

Serum samples for assessment of anti-trebananib binding and neutralizing antibodies (as previously described) ${ }^{44}$ were collected predose; at weeks 1, 5, and 10; every $9 \pm 1$ weeks thereafter; and at the safety follow-up visit.

\section{Statistical Analyses}

OR, DOR, and tumor burden were determined for the subset of patients with at least one unidimensionally measurable lesion at baseline for each cohort. Safety analyses and analysis of PFS included all patients who received $\geq 1$ dose of trebananib and reported by descriptive statistics (eg, percentage). Exact binomial 2sided $80 \%$ confidence intervals (CIs) were generated for OR for each cohort. For PFS and DOR, medians with 95\% CIs were calculated using the Kaplan-Meier method for each cohort. Noncompartmental pharmacokinetic analyses for detection of trebananib, trastuzumab, and paclitaxel were done using Phoenix WinNonlin 6.3 software (Pharsight, St. Louis, MO).

\section{Results}

\section{Patient Characteristics}

A total of 40 women were enrolled at 16 centers in Belgium, France, and the United States. Twenty were in the trebananib 10 $\mathrm{mg} / \mathrm{kg}$ once a week plus trastuzumab/paclitaxel cohort, and 20 were in the trebananib $30 \mathrm{mg} / \mathrm{kg}$ once a week plus trastuzumab/paclitaxel cohort (Table 1). At the time of this analysis, all but one patient in the trebananib $30 \mathrm{mg} / \mathrm{kg}$ cohort had discontinued study treatment (Figure 1). Key reasons for discontinuation of trebananib were disease progression (trebananib $10 \mathrm{mg} / \mathrm{kg}, \mathrm{n}=9$; trebananib 30 $\mathrm{mg} / \mathrm{kg}, \mathrm{n}=6$ ) and AEs (trebananib $10 \mathrm{mg} / \mathrm{kg}, \mathrm{n}=6$; trebananib $30 \mathrm{mg} / \mathrm{kg}, \mathrm{n}=9$ ). Median (range) number of trebananib infusions was 29.5 (1-173) in the trebananib $10 \mathrm{mg} / \mathrm{kg}$ cohort and 25.5 (13138 ) in the trebananib $30 \mathrm{mg} / \mathrm{kg}$ cohort. Median (range) number of trastuzumab cycles was $12.0(2-60)$ in the trebananib $10 \mathrm{mg} / \mathrm{kg}$ cohort and 15.0 (5-77) in the trebananib $30 \mathrm{mg} / \mathrm{kg}$ cohort. Patients received a median (range) of $6.0(2-11)$ paclitaxel cycles in the trebananib $10 \mathrm{mg} / \mathrm{kg}$ cohort and 8.0 (3-19) in the trebananib $30 \mathrm{mg} / \mathrm{kg}$ cohort.

\section{$D L T s$ and $A E s$}

Two patients experienced DLTs during the first 21 days of the study. One patient in the trebananib $10 \mathrm{mg} / \mathrm{kg}$ cohort experienced a grade 3 ocular, arterial thromboembolic transient ischemic attack on day 11 and discontinued the study. The event was considered to be related to trebananib by the investigator but was not deemed serious. One patient in the trebananib $30 \mathrm{mg} / \mathrm{kg}$ cohort experienced a grade 3 elevation in $\gamma$-glutamyl transferase on day 21 of the study. The DLT was considered to be related to trebananib and paclitaxel but was not considered serious by the investigator. Treatment was delayed by 3 days, the event resolved by day 25, and the patient was not removed from the study. Given the low incidence of DLTs, both cohorts were expanded to 20 patients to further evaluate toxicity and efficacy of trebananib in combination with trastuzumab and paclitaxel.

All patients experienced at least one treatment-emergent AE. Grade 3 or higher AEs were reported in 16 patients $(80 \%)$ in the trebananib $10 \mathrm{mg} / \mathrm{kg}$ cohort and 13 patients $(65 \%)$ in the trebananib $30 \mathrm{mg} / \mathrm{kg}$ cohort. Six (30\%) and $9(45 \%)$ patients had serious treatment-emergent AEs in the trebananib 10 and $30 \mathrm{mg} / \mathrm{kg}$ cohorts, respectively; $6(30 \%)$ and $8(40 \%)$ patients in the trebananib 10 and $30 \mathrm{mg} / \mathrm{kg}$ cohorts, respectively, had treatment-emergent AEs that led to discontinuation of trebananib. The only AE that led to discontinuation of trebananib in more than one patient was peripheral edema ( $\mathrm{n}=2$ in the trebananib $30 \mathrm{mg} / \mathrm{kg}$ cohort).

The most frequently occurring AEs were peripheral edema, fatigue, diarrhea, alopecia, nausea, nail disorder, and rash (Table 2). Most events were mild to moderate in severity. The most frequently occurring grade 3 or higher AEs were peripheral neuropathy, 


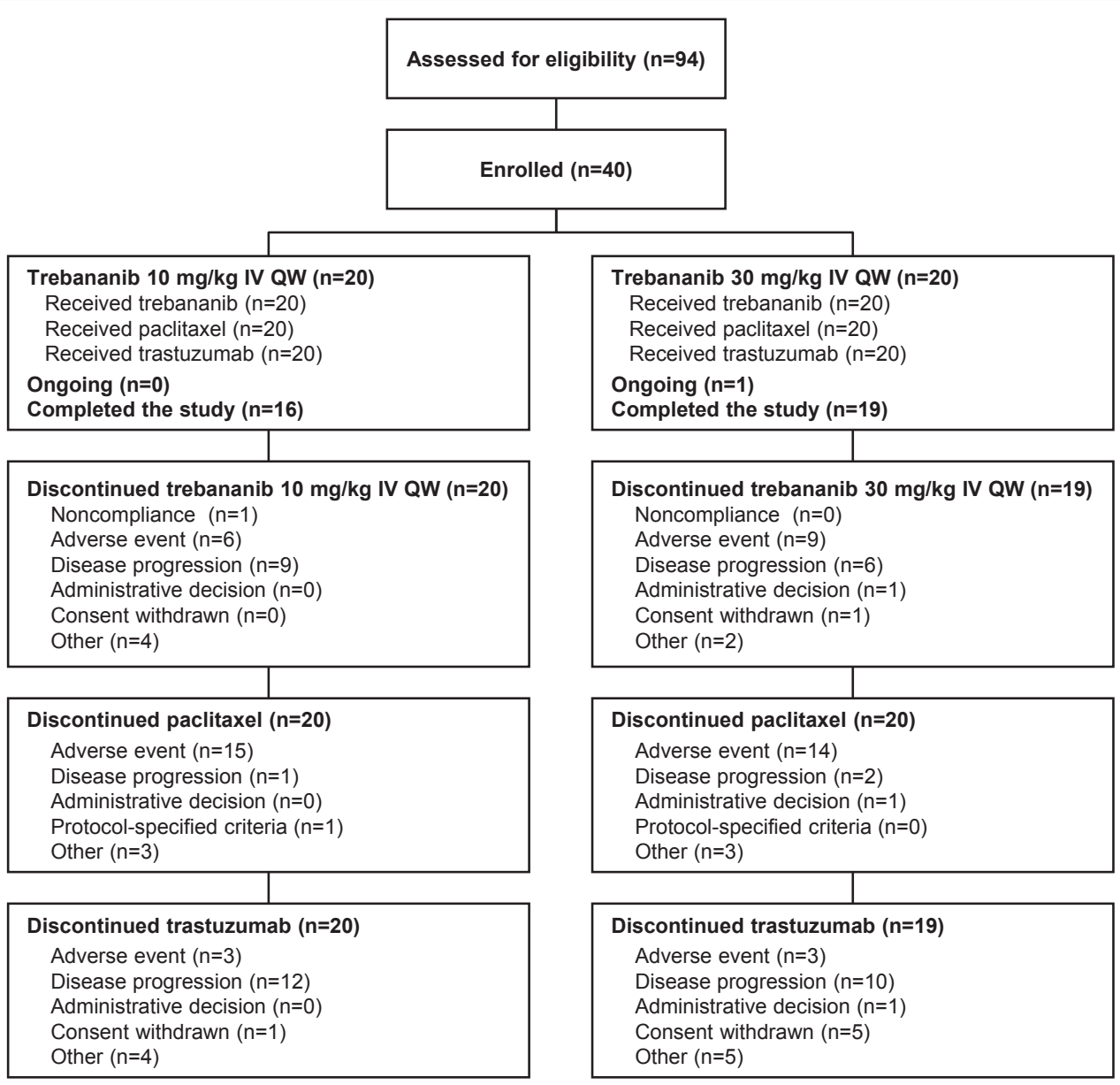

peripheral sensory neuropathy, and dyspnea (Table 2). Two patients had grade 4 events (neutropenia and ankle fracture, both in the trebananib $10 \mathrm{mg} / \mathrm{kg}$ cohort). Five patients (25\%) in the trebananib $30 \mathrm{mg} / \mathrm{kg}$ cohort and $2(10 \%)$ in the trebananib $10 \mathrm{mg} / \mathrm{kg}$ cohort had pleural effusion. One pleural effusion event in the trebananib $30 \mathrm{mg} / \mathrm{kg}$ cohort was grade 3 ; all others were grade $1 / 2$. There were no fatal AEs.

AEs of interest are shown in Table 3. Two patients (10\%) in the trebananib $30 \mathrm{mg} / \mathrm{kg}$ cohort had grade 3 peripheral edema. There were no other grade 3 or higher peripheral edema events. Five patients $(3$ in the trebananib $10 \mathrm{mg} / \mathrm{kg}$ cohort and 2 in the trebananib $30 \mathrm{mg} / \mathrm{kg}$ cohort) had grade 1 blurred vision. No patient had ascites during the study. Incidences of hypertension and arterial and venous thromboembolic events were low (Table 3). Three patients in the trebananib $30 \mathrm{mg} / \mathrm{kg}$ cohort experienced decreased left ventricular ejection fraction, one of which was grade 3.

\section{Efficacy}

At the time of this analysis, 12 patients $(60 \%)$ in the trebananib $10 \mathrm{mg} / \mathrm{kg}$ cohort and 9 patients (45\%) in the trebananib $30 \mathrm{mg} / \mathrm{kg}$ cohort had disease progression or died. Median (95\% CI) PFS for patients in the trebananib 10 and $30 \mathrm{mg} / \mathrm{kg}$ trebananib cohorts was 14.5 (6.9-20.6) and 18.5 (10.4-21.9) months, respectively (Figure 2A). OR was confirmed in 31 (84\%) of 37 patients with measurable disease at baseline. Among the 20 patients in the trebananib $10 \mathrm{mg} / \mathrm{kg}$ cohort, none had a complete response and 16 patients $(80 \%)$ had a partial response (OR, 80\%; 95\% CI, 56-94). In the trebananib $30 \mathrm{mg} / \mathrm{kg}$ cohort, 17 patients had measurable disease. Of these $17,3(18 \%)$ had a complete response and 12 (71\%) had a partial response (OR, 88\%; 95\% CI, 64-98). Median $(95 \% \mathrm{CI})$ DOR for responders in the trebananib 10 and $30 \mathrm{mg} / \mathrm{kg}$ cohorts was 12.6 (4.3-20.2) and 16.6 (8.2-not estimable) months, respectively. Mean (standard deviation [SD]) decrease in the sum of the longest diameters of target lesions from baseline was 61\% (25\%) and $69 \%(24 \%)$ in the trebananib 10 and $30 \mathrm{mg} / \mathrm{kg}$ cohorts (Figure 2B).

\section{Pharmacokinetics}

For trebananib, mean (SD) maximum observed concentration $\left(\mathrm{C}_{\max }\right)$ and area under the concentration-time curve within a dosing interval $\left(\mathrm{AUC}_{\mathrm{tau}}\right)$, respectively, at steady state were 242 (82.6) $\mu \mathrm{g} / \mathrm{mL}$ and 8.22 (3.59) $\mathrm{mg} \bullet \mathrm{h} / \mathrm{mL}$ following $10 \mathrm{mg} / \mathrm{kg}$ 


\section{Trebananib-Paclitaxel-Trastuzumab in Breast Cancer}

Table 2 Treatment-Emergent AEs Occurring in $\geq 20 \%$ of Patients

\begin{tabular}{|c|c|c|c|c|}
\hline \multirow[b]{2}{*}{ AE } & \multicolumn{2}{|c|}{$\begin{array}{l}\text { Trebananib } 10 \mathrm{mg} / \mathrm{kg}+\text { Trastuzumab/Paclitaxel } \\
\qquad(\mathrm{n}=20)^{\mathrm{a}}\end{array}$} & \multicolumn{2}{|c|}{$\begin{array}{l}\text { Trebananib } 30 \mathrm{mg} / \mathbf{k g}+\text { Trastuzumab/Paclitaxel } \\
\qquad(\mathrm{n}=20)^{\mathrm{b}}\end{array}$} \\
\hline & Any Grade & Grade 3 or Higher & Any Grade & Grade 3 or Higher \\
\hline Any AE & $20(100)$ & $16(80)$ & $20(100)$ & $13(65)$ \\
\hline \multicolumn{5}{|c|}{$\begin{array}{l}\text { AEs occurring in } \geq 20 \% \text { of } \\
\text { patients }\end{array}$} \\
\hline Peripheral edema & $13(65)$ & 0 & $15(75)$ & $2(10)$ \\
\hline Fatigue & $15(75)$ & $2(10)$ & $9(45)$ & 0 \\
\hline Diarrhea & $13(65)$ & 0 & $14(70)$ & 0 \\
\hline Alopecia & $13(65)$ & 0 & $13(65)$ & 0 \\
\hline Nausea & $11(55)$ & 0 & $13(65)$ & 0 \\
\hline Nail disorder & $12(60)$ & $2(10)$ & $7(35)$ & 0 \\
\hline Rash & $12(60)$ & $1(5)$ & $6(30)$ & 0 \\
\hline Dyspnea & $10(50)$ & $3(15)$ & $7(35)$ & $1(5)$ \\
\hline $\begin{array}{l}\text { Peripheral sensory } \\
\text { neuropathy }\end{array}$ & $10(50)$ & $4(20)$ & $4(20)$ & 0 \\
\hline Paresthesia & $3(15)$ & $1(5)$ & $10(50)$ & $2(10)$ \\
\hline Headache & $9(45)$ & 0 & $8(40)$ & 0 \\
\hline Neutropenia & $9(45)$ & $1(5)$ & $8(40)$ & $1(5)$ \\
\hline Epistaxis & $5(25)$ & 0 & $9(45)$ & 0 \\
\hline Pain in extremity & $9(45)$ & 0 & $5(25)$ & 0 \\
\hline Arthralgia & $9(45)$ & 0 & $3(15)$ & 0 \\
\hline Decreased appetite & $9(45)$ & 0 & $2(10)$ & 0 \\
\hline Constipation & $7(35)$ & 0 & $8(40)$ & 0 \\
\hline Cough & $8(40)$ & 0 & $6(30)$ & 0 \\
\hline Insomnia & $5(25)$ & 0 & $8(40)$ & 0 \\
\hline Peripheral neuropathy & $8(40)$ & $4(20)$ & $5(25)$ & $4(20)$ \\
\hline Edema & $8(40)$ & 0 & $5(25)$ & 0 \\
\hline Asthenia & $2(10)$ & 0 & $8(40)$ & $1(5)$ \\
\hline Back pain & $6(30)$ & 0 & $5(25)$ & 0 \\
\hline Dysgeusia & $5(25)$ & 0 & $6(30)$ & 0 \\
\hline Vomiting & $6(30)$ & 0 & $5(25)$ & 0 \\
\hline Hypertension & $6(30)$ & $1(5)$ & $4(20)$ & 0 \\
\hline Abdominal pain & $3(15)$ & 0 & $6(30)$ & 0 \\
\hline Dyspepsia & $6(30)$ & 0 & $3(15)$ & 0 \\
\hline Lymphedema & $3(15)$ & 0 & $6(30)$ & 0 \\
\hline Pain & $6(30)$ & 0 & $2(10)$ & 0 \\
\hline Weight increased & $2(10)$ & 0 & $6(30)$ & 0 \\
\hline Dizziness & $5(25)$ & 0 & $4(20)$ & 0 \\
\hline Oropharyngeal pain & $5(25)$ & 0 & $4(20)$ & 0 \\
\hline Pyrexia & $4(20)$ & 0 & $5(25)$ & 0 \\
\hline Breast pain & $5(25)$ & 0 & $3(15)$ & 0 \\
\hline Urinary tract infection & $5(25)$ & 0 & $3(15)$ & 0 \\
\hline
\end{tabular}

Data are presented as $n(\%)$.

Abbreviation: $\mathrm{AE}=$ adverse event.

Two patients in the trebananib $10 \mathrm{mg} / \mathrm{kg}$ cohort had grade 4 AEs (neutropenia and ankle fracture, respectively); no patients had grade 5 AEs.

${ }^{\mathrm{b}}$ None of patients in the trebananib $30 \mathrm{mg} / \mathrm{kg}$ cohort had grade 4 or $5 \mathrm{AEs}$.

weekly infusion of trebananib and $781(170) \mu \mathrm{g} / \mathrm{mL}$ and 31.1 (8.92) $\mathrm{mg} \bullet / \mathrm{hL}$ following $30 \mathrm{mg} / \mathrm{kg}$ weekly infusion of trebananib (Table 4). Mean (SD) concentration-time profiles for trebananib at steady state (week 7) are shown in Figure 3. Clearance and volume of distribution at steady-state estimates of trebananib were similar between treatment groups. For trastuzumab, $\mathrm{C}_{\max }$ and $\mathrm{AUC}_{\text {tau }}$ were similar between dose cohorts, suggesting that the higher trebananib dose did not influence the pharmacokinetics of trastuzumab. Trastuzumab $\mathrm{C}_{\max }$ at week 7 was $156(30.5) \mu \mathrm{g} / \mathrm{mL}$ and 158 (34.2) $\mu \mathrm{g} / \mathrm{mL}$ in the trebananib $10 \mathrm{mg} / \mathrm{kg}$ cohort and $30 \mathrm{mg} / \mathrm{kg}$ cohorts, 


\begin{tabular}{|c|c|c|c|c|}
\hline \multirow[b]{2}{*}{ AE } & \multicolumn{2}{|c|}{ Trebananib $10 \mathrm{mg} / \mathrm{kg}(\mathrm{n}=20)$} & \multicolumn{2}{|c|}{ Trebananib $30 \mathrm{mg} / \mathrm{kg}(\mathrm{n}=20)$} \\
\hline & Any Grade & Grade 3 or Higher & Any Grade & Grade 3 or Higher \\
\hline Edema (all types) ${ }^{a}$ & $18(90)$ & 0 & $20(100)$ & $3(15)$ \\
\hline Peripheral edema $^{\mathrm{b}}$ & $13(65)$ & 0 & $15(75)$ & $2(10)$ \\
\hline Generalized edema $^{\mathrm{C}}$ & $1(5)$ & 0 & $3(15)$ & $1(5)$ \\
\hline Lymphedema & $3(15)$ & 0 & $6(30)$ & 0 \\
\hline Hemorrhage $^{d}$ & $6(30)$ & 0 & $10(50)$ & 0 \\
\hline Hypertension & $6(30)$ & $1(5)$ & $5(25)$ & 0 \\
\hline Pleural effusion & $2(10)$ & 0 & $5(25)$ & $1(5)$ \\
\hline Blurred vision & $3(15)$ & 0 & $2(10)$ & 0 \\
\hline \multicolumn{5}{|l|}{ Thromboembolic events } \\
\hline Venous & $1(5)$ & 0 & $2(10)$ & $1(5)$ \\
\hline Arterial & $1(5)$ & $1(5)^{e}$ & 0 & 0 \\
\hline $\begin{array}{l}\text { Decreased left ventricular } \\
\text { ejection fraction }\end{array}$ & 0 & 0 & $3(15)$ & $1(5)$ \\
\hline
\end{tabular}

Abbreviation: $A E=$ adverse event

${ }^{\text {a }}$ Specific subtypes of edema listed were chosen based on incidence in $\geq 25 \%$ of patients in either cohort.

befined as edema confined to single body area.

cDefined as edema with contiguous extension to more than single body area.

dEighty-seven percent of events were epistaxis; $80 \%$ in the trebananib $10 \mathrm{mg} / \mathrm{kg}$ cohort and $100 \%$ in the trebananib $30 \mathrm{mg} / \mathrm{kg}$ cohort were grade 1.

'This event, an ocular transient ischemic attack, was noted as a dose-limiting toxicity.

respectively. Trastuzumab $\mathrm{AUC}_{\text {tau }}$ was 21.7 (4.39) $\mathrm{mg} \bullet \mathrm{h} / \mathrm{mL}$ and $24.0(6.30) \mathrm{mg} \bullet \mathrm{h} / \mathrm{mL}$ in the trebananib 10 and $30 \mathrm{mg} / \mathrm{kg}$ cohorts, respectively. The pharmacokinetics of paclitaxel was also not affected by the coadministration of trebananib. For the trebananib $10 \mathrm{mg} / \mathrm{kg}$ cohort, mean (SD) paclitaxel $\mathrm{C}_{\max }$ was 2310 (1100) $\mathrm{ng} / \mathrm{mL}$ at week 1 and $2490(728) \mathrm{ng} / \mathrm{mL}$ at week 7; mean (SD) area under the concentration-time curve to the last measurable concentration $\left(\mathrm{AUC}_{\text {inf }}\right)$ of paclitaxel was $5440(1830) \mathrm{ng} \bullet \mathrm{h} / \mathrm{mL}$ at week 1 and 5220 (1470) $\mathrm{ng} \bullet \mathrm{h} / \mathrm{mL}$ at week 7. For the trebananib $30 \mathrm{mg} / \mathrm{kg}$ cohort, mean (SD) paclitaxel $\mathrm{C}_{\max }$ was 1940 (919) $\mathrm{ng} / \mathrm{mL}$ at week 1 and 2020 (1040) ng/mL at week 7, and mean (SD) paclitaxel AUC ${ }_{\text {inf }}$ was 4550 (1180) ng•h/mL at week 1 and $4310(1020) \mathrm{ng} \bullet / \mathrm{mL}$ at week 7.

\section{Anti-Trebananib Antibodies}

Three (11\%) of 27 patients had anti-trebananib binding, but nonneutralizing, antibodies at baseline $(\mathrm{n}=1$, trebananib $10 \mathrm{mg} /$ $\mathrm{kg} ; \mathrm{n}=2$, trebananib $30 \mathrm{mg} / \mathrm{kg}$ ). No patients developed binding or neutralizing anti-trebananib antibodies during the study. Positivity for anti-trebananib binding antibodies did not appear to affect the pharmacokinetics of trebananib.

\section{Discussion}

In this phase $1 \mathrm{~b}$ study, administration of trebananib (10 or 30 $\mathrm{mg} / \mathrm{kg}$ once a week) in combination with paclitaxel and trastuzumab in women with HER2-positive locally recurrent or metastatic breast cancer resulted in a toxicity profile consistent with that anticipated for the combination. Most treatment-related AEs were grade 1 or 2, and there was no evidence of pharmacokinetic interactions between these agents. The activity of the combination was notable: overall, more than $80 \%$ of patients had an OR; PFS and DOR results were promising in these patients when compared with historical controls.
AEs occurring in this study were consistent with previously reported findings $^{38-41}$ and showed that a combination of trebananib, trastuzumab, and paclitaxel did not result in unanticipated toxicity. The most frequently occurring AE was peripheral edema; this was grade 1 or 2 in most cases and infrequently resulted in discontinuation of study treatment. Edema and pleural effusion have been associated with trebananib and occurred at similar rates in this study as those seen in previous reports. Pleural effusion occurred in 5\% of patients given trebananib 3 or $10 \mathrm{mg} / \mathrm{kg}$, and edema occurred in $13 \%$ to $61 \%$ of patients. ${ }^{45,46}$ Because trebananib binds to and inactivates angiopoietins 1 and 2 , the vascular permeability and the normal flow of the lymphatic and venous circulation can be perturbed, which may lead to accumulation of extracellular fluid in general and (lymph) edema. In most cases, edema is generally mild and reversible but usually takes 4 to 12 months to resolve after stopping trebananib. ${ }^{45}$ Other AEs, such as fatigue, rash, diarrhea, and headache, were mild and were consistent with previously published findings from studies in which trebananib was administered as a single agent ${ }^{30}$ or in combination ${ }^{37}$ with paclitaxel. Previous studies in combination with paclitaxel were conducted at doses of trebananib 10 or $15 \mathrm{mg} / \mathrm{kg}$ once a week. This study suggests that doses of trebananib of up to $30 \mathrm{mg} / \mathrm{kg}$ once a week in combination with paclitaxel (and trastuzumab) are tolerable. AEs that are typically associated with anti-VEGF pathway agents (eg, hypertension, impaired wound healing, and thrombosis $)^{47}$ were infrequent, demonstrating the distinct toxicity profile of trebananib.

The pharmacokinetics of trebananib appeared to be dose proportional at the doses tested, and exposure was similar to that in previous monotherapy studies at the same $\operatorname{doses}^{30}$ and for the combination of trebananib $10 \mathrm{mg} / \mathrm{kg}$ and paclitaxel. ${ }^{41}$ This study did not identify an effect of trebananib on the pharmacokinetic profile of either trastuzumab or paclitaxel. Pharmacokinetic 


\section{Trebananib-Paclitaxel-Trastuzumab in Breast Cancer}

Figure 2 Analysis of PFS and Lesion SLD. (A) Kaplan-Meier Analysis of Median PFS. (B) Change in SLD of Target Lesions by Best Response. Data From all Patients With at Least One Measurable Lesion per Modified RECIST are Shown. One Patient in Each Cohort $\left(^{*}\right)$ had a $>30 \%$ Reduction in SLD of Target Lesions With No Confirmatory Tumor Assessment and Was Therefore Assigned Best Response of SD

$\mathbf{A}$

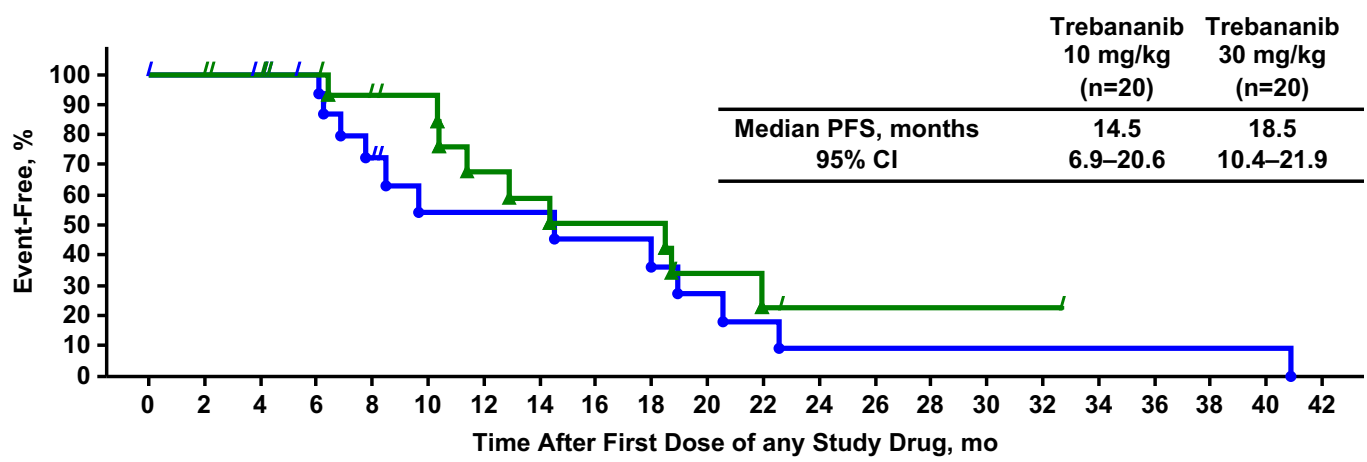

Number of patients at risk immediately before time point

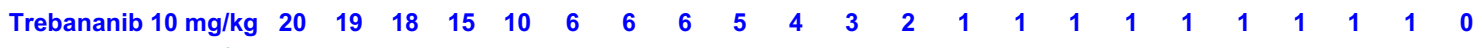

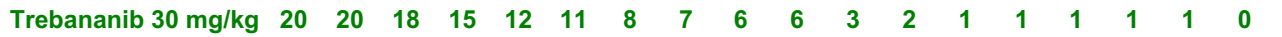

$\mathbf{B}$

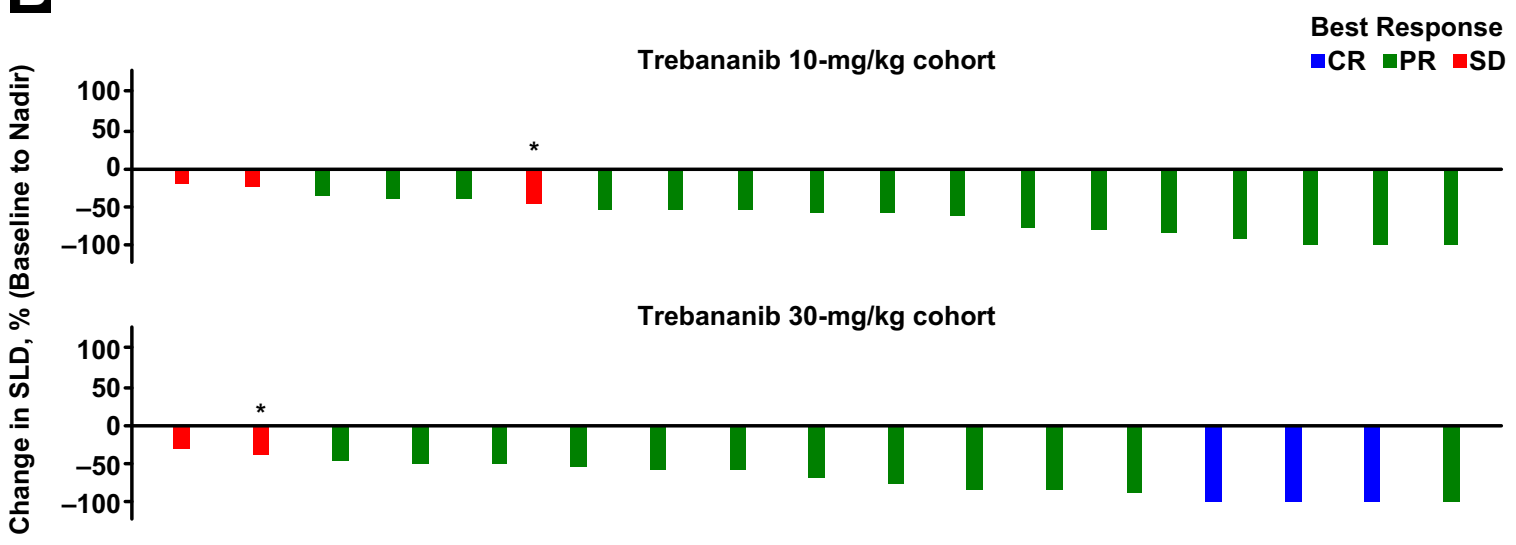

Abbreviations: $\mathrm{CR}=$ complete response; $\mathrm{PFS}=$ progression-free survival; $\mathrm{PR}=$ partial response; RECIST $=$ Response Evaluation Criteria in Solid Tumors; $\mathrm{SD}=$ stable disease; SLD = sum of longest diameter.

interactions for the 3 agents evaluated were not anticipated because trebananib is cleared by the neonatal Fc receptor and via the kidney, ${ }^{48}$ whereas trastuzumab is metabolized following recycling by the neonatal Fc receptor ${ }^{49}$ and paclitaxel is metabolized by cytochrome P450 enzymes. ${ }^{50}$ As reported previously for other combinations, ${ }^{35,41}$ the presence of anti-trebananib antibodies did not affect the pharmacokinetic profile of trebananib, trastuzumab, or paclitaxel.

Table 4 Steady-State Trebananib Pharmacokinetic Parameter Estimates at Week 7

\begin{tabular}{|c|c|c|c|c|c|c|}
\hline \multirow[b]{2}{*}{ Parameter } & \multicolumn{3}{|c|}{ Trebananib 10 mg/kg Cohort } & \multicolumn{3}{|c|}{ Trebananib 30 mg/kg Cohort } \\
\hline & $\mathbf{n}$ & Mean (SD) & CV (\%) & $\mathbf{n}$ & Mean (SD) & CV (\%) \\
\hline $\mathrm{C}_{\mathrm{max}, \mathrm{ss}}, \mu \mathrm{g} / \mathrm{mL}$ & 18 & $242(82.6)$ & 34.1 & 17 & $781(170)$ & 21.8 \\
\hline$A U C_{\text {tau,ss }}, \mathrm{mg} \bullet \mathrm{h} / \mathrm{mL}$ & 17 & $8.22(3.59)$ & 43.7 & 11 & $31.1(8.92)$ & 28.7 \\
\hline $\mathrm{C}_{\mathrm{L}}, \mathrm{mL} / \mathrm{h} / \mathrm{kg}$ & 18 & $1.39(0.454)$ & 32.7 & 11 & $1.07(0.537)$ & 50.1 \\
\hline $\mathrm{V}_{\mathrm{sS}}, \mathrm{mL} / \mathrm{kg}$ & 18 & $55.7(21.5)$ & 38.6 & 11 & $51.2(21.4)$ & 41.9 \\
\hline $\mathrm{C}_{\min }, \mu \mathrm{g} / \mathrm{mL}$ & 16 & $15.3(8.46)$ & 55.5 & 12 & $65.3(30.4)$ & 46.6 \\
\hline
\end{tabular}

Abbreviations: $\mathrm{AUC}_{\text {tau,ss }}=$ area under the concentration-time curve from time 0-168 hours at steady state; $C_{\mathrm{L}}=$ serum clearance after intravenous infusion; $C_{\text {max,ss }}=$ maximum observed drug concentration at steady state; $\mathrm{C}_{\min }=$ minimum observed drug concentration during dosing interval; $\mathrm{CV}=$ coefficient of variation; $\mathrm{SD}=\mathrm{standard}$ deviation; $\mathrm{V}_{\mathrm{SS}}=$ volume of distribution at steady state. 


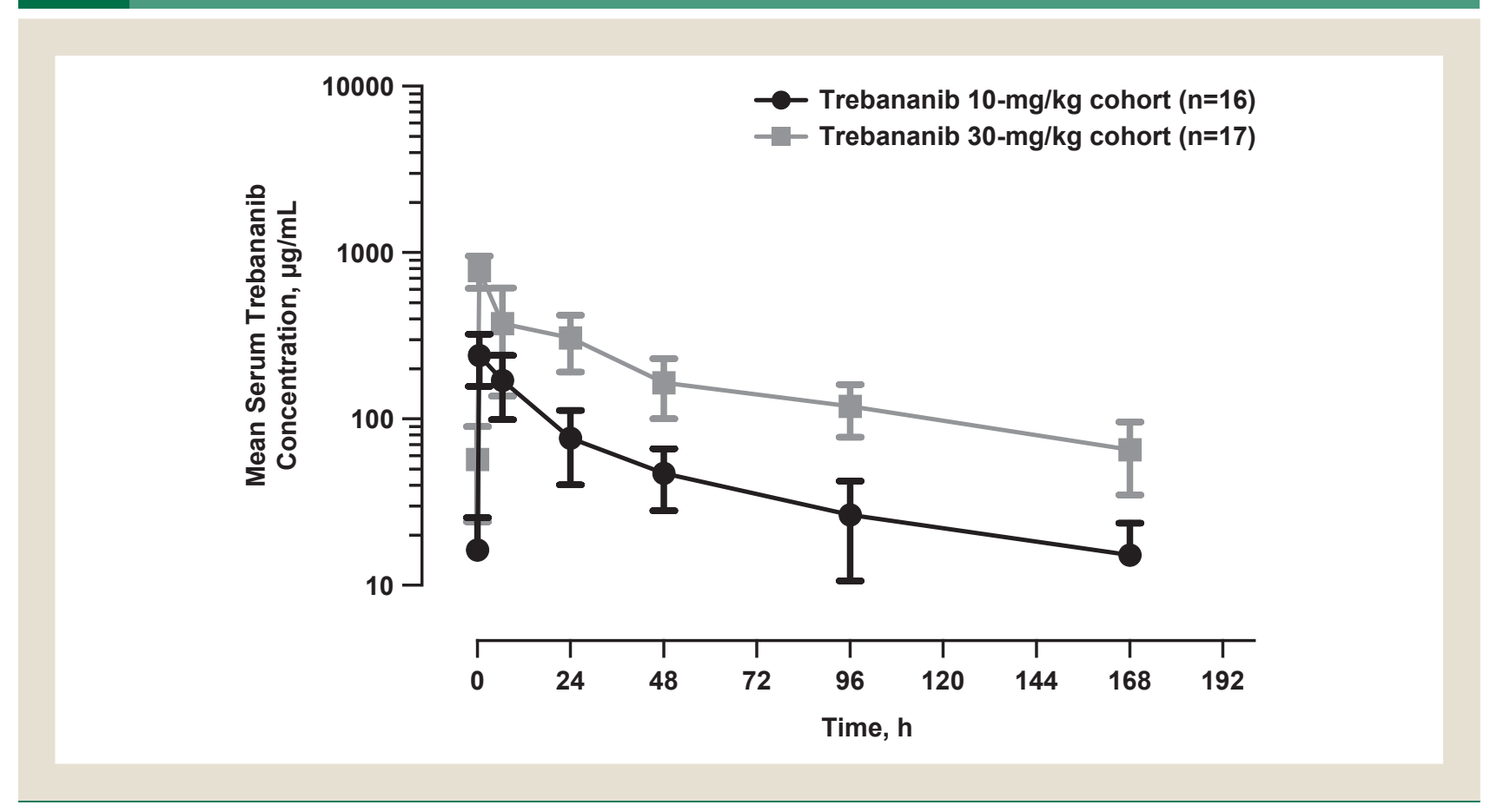

This was a small phase $1 \mathrm{~b}$ study and as such has a number of limitations. Evaluation of antitumor activity was exploratory, and results must be interpreted cautiously when compared with historical controls. Furthermore, because the 10 and $30 \mathrm{mg} / \mathrm{kg}$ once a week cohorts were nonrandomized and sequentially enrolled, comparison of the safety and efficacy data of the 2 cohorts must be viewed with caution. Nevertheless, the results provide preliminary evidence of antitumor activity in patients given either the 10 or $30 \mathrm{mg} / \mathrm{kg}$ once a week dose of trebananib in combination with trastuzumab and paclitaxel. OR in this study $(80 \%$ in the trebananib $10 \mathrm{mg} / \mathrm{kg}$ cohort; $88 \%$ in the trebananib $30 \mathrm{mg} / \mathrm{kg}$ cohort) compares favorably with previous phase 3 studies that have reported response rates from $36 \%$ to $62 \%$ with the combination of trastuzumab and paclitaxel in women with HER2-positive advanced breast cancer. ${ }^{8-10}$ Similarly, PFS in this study (14.5 months in the trebananib $10 \mathrm{mg} / \mathrm{kg}$ cohort; 18.5 months in the trebananib $30 \mathrm{mg} / \mathrm{kg}$ cohort) appears longer than time to progression or PFS times observed in previous studies (7.4-14.5 months). ${ }^{8-10}$ It is important to note that the combination of pertuzumab, trastuzumab, and docetaxel is now considered standard treatment for HER2-positive metastatic breast cancer. ${ }^{51,52}$ In the phase 3 CLEOPATRA study, PFS was prolonged by 6.1 months, from 12.4 months in the control group (placebo/docetaxel/trastuzumab) to 18.5 months in the pertuzumab/docetaxel/trastuzumab group (hazard ratio $=0.62 ; 95 \% \mathrm{CI}, 0.51-0.75 ; P<.001$ ). Similarly, AEs in the CLEOPATRA clinical study were mild and included diarrhea, rash, mucosal inflammation, febrile neutropenia, and dry skin. ${ }^{14}$ These findings suggest that the addition of trebananib to trastuzumab/paclitaxel/pertuzumab may provide further benefit.

Several phase 2 and 3 clinical studies have evaluated the combination of the VEGF inhibitor bevacizumab with trastuzumab plus chemotherapy in different lines of treatment in patients with
HER2-positive breast cancer. In the AVEREL phase 3 study of bevacizumab, trastuzumab, and docetaxel in HER2-positive metastatic breast cancer, median PFS was 16.5 and 13.7 months in the bevacizumab and nonbevacizumab arms, respectively; however, the difference was not statistically significant (hazard ratio $=0.82 ; 95 \%$ CI, $0.65-10.02 ; P=.0775) .{ }^{25}$ In the adjuvant phase $3 \mathrm{BETH}$ trial, the addition of bevacizumab to adjuvant trastuzumab and chemotherapy also did not significantly improve invasive disease-free survival or overall survival in patients with high-risk HER2-positive breast cancer. ${ }^{53}$ In a neoadjuvant phase 2 clinical trial (BEVERLY2), which was conducted specifically in patients with inflammatory nonmetastatic HER2-positive breast cancer, bevacizumab, trastuzumab, and chemotherapy produced a complete pathologic response in 33 of 52 patients with nonmetastatic HER2-positive primary breast cancer, which was higher than historical data on this population of patients. ${ }^{54}$ Furthermore, a neoadjuvant randomized phase 2 trial in noninflammatory HER2-positive breast cancer has also failed to demonstrate a substantial benefit of the addition of bevacizumab to trastuzumab and chemotherapy because of increased AEs. ${ }^{55}$ A phase 2 study of lapatinib in combination with bevacizumab in heavily pretreated patients with HER2-positive breast cancer has shown activity with the addition of bevacizumab, ${ }^{56}$ but no randomized trials have been completed to date. Finally, multiple studies in other tumor types (eg, colorectal, nonsmall-cell lung cancer, squamous cell carcinoma of the head and neck) have investigated the value of dual inhibition of the EGF/ HER and VEGF pathways; several have demonstrated antitumor activity, with some showing improvements in PFS. ${ }^{57-59}$ Hence, the clinical value of the addition of the VEGF inhibitor bevacizumab to EGF/HER targeted therapies in breast and other tumor types remains unclear. This study of trebananib in combination with trastuzumab in metastatic breast cancer suggests that inhibition of 


\section{Trebananib-Paclitaxel-Trastuzumab in Breast Cancer}

Ang1/Ang2 modulated angiogenesis may be an important alternative approach to combined blockade of HER2 signaling and angiogenesis. A more definitive assessment of efficacy of the combination of HER and Ang1/Ang2 inhibition would require larger randomized, placebo-controlled studies, such studies are not currently planned.

\section{Conclusion}

This phase $1 \mathrm{~b}$ study showed that the combination of trebananib $(10 \mathrm{mg} / \mathrm{kg}$ or $30 \mathrm{mg} / \mathrm{kg}$ weekly), trastuzumab, and paclitaxel has acceptable toxicity in women with HER2-positive locally recurrent or metastatic breast cancer. Preliminary evidence suggests that the combination had antitumor activity in patients with HER2-positive metastatic breast cancer. The data suggest that further investigation of Ang1/Ang2 inhibition in combination with HER2 (and other members of the HER family of receptors) may be warranted.

\section{Clinical Practice Points}

- HER2 is amplified in approximately $20 \%$ to $25 \%$ of patients with breast cancer, and overexpression has been shown to be associated with a clinically aggressive form of the disease. Furthermore, HER2 overexpression has been shown to up-regulate Ang2 in breast cancer cell lines, suggesting that HER2 tumors might be particularly susceptible to therapies that target angiopoietins.

- Trebananib is a peptide-Fc fusion protein that binds Ang1 and Ang2 and prevents their interaction with the Tie2 receptor, and has demonstrated tolerability and efficacy in combination with chemotherapy in large phase 3 trials in ovarian cancer. This study is the first to report data on the use of an angiopoietin inhibitor, trebananib, in combination with trastuzumab and paclitaxel in HER2-positive metastatic breast cancer.

- Results demonstrated an acceptable toxicity profile consistent with that anticipated for the combination. Most treatmentrelated AEs were grade 1 or 2, and there was no evidence of pharmacokinetic interactions between these agents. Additionally, the activity of the combination was notable: overall, more than $80 \%$ of patients had an OR; PFS and DOR were promising when compared with historical controls.

- The data suggest that further investigation of Ang1/Ang2 inhibition in combination with HER2 (and other members of the HER family of receptors) may be beneficial.

\section{Acknowledgments}

The authors thank Jennifer Venzie, PhD, and Miranda Tradewell, PhD (Complete Healthcare Communications LLC, North Wales, PA), for editorial assistance, which was funded by Amgen Inc. This study was funded by Amgen Inc, which was involved in the study design, the collection, analysis, and interpretation of data, in the writing of the report, and in the decision to submit for publication. Dr. Kaufman has received consulting fees from Amgen Inc and that he holds stocks in Amgen Inc.

\section{Disclosure}

P.A.K.'s institution received grants from Amgen Inc; H.W.'s institution received speaker's fees from Amgen Inc; G.F. has acted as a consultant for Amgen France; G.J. has received grants from
Novartis and Roche, personal fees from Novartis, Roche, Pfizer, Lilly, Celgene, Amgen Inc, BMS, Puma Biotechnology, and Daiichi-Sankyo, nonfinancial support from Novartis, Roche, Pfizer, and Lilly, and his institution received investigator fees from Amgen Inc; A.S. has received grants and personal fees from Amgen Inc and personal fees from Novartis; B.W. was an employee of Amgen Inc at the time this study was conducted; and C.A.P. is an employee of and holds stock options in Amgen Inc. The other authors have stated that they have no conflict of interest.

\section{References}

1. Banerjee S, Dowsett M, Ashworth A, et al. Mechanisms of disease: angiogenesis and the management of breast cancer. Nat Clin Pract Oncol 2007; 4:536-50.

2. Slamon DJ, Clark GM, Wong SG, et al. Human breast cancer: correlation of relapse and survival with amplification of the HER-2/neu oncogene. Science 1987; 235:177-82.

3. Arteaga CL, Engelman JA. ERBB receptors: from oncogene discovery to basic science to mechanism-based cancer therapeutics. Cancer Cell 2014; 25:282303.

4. Dokala A, Thakur SS. Extracellular region of epidermal growth factor receptor: potential target for anti-EGFR drug discovery. Oncogene 2017; 36:2337-44.

5. Kumar R, Yarmand-Bagheri R. The role of HER2 in angiogenesis. Semin Oncol 2001; 28 (5 suppl 16):27-32.

6. Wen XF, Yang G, Mao W, et al. HER2 signaling modulates the equilibrium between pro- and antiangiogenic factors via distinct pathways: implications for HER2-targeted antibody therapy. Oncogene 2006; 25:6986-96.

7. Slamon DJ, Godolphin W, Jones LA, et al. Studies of the HER-2/neu protooncogene in human breast and ovarian cancer. Science 1989; 244:707-12.

8. Slamon DJ, Leyland-Jones B, Shak S, et al. Use of chemotherapy plus a monoclonal antibody against HER2 for metastatic breast cancer that overexpresses HER2. N Engl J Med 2001; 344:783-92.

9. Baselga J, Manikhas A, Cortes J, et al. Phase III trial of nonpegylated liposomal doxorubicin in combination with trastuzumab and paclitaxel in HER2-positive metastatic breast cancer. Ann Oncol 2014; 25:592-8.

10. Robert N, Leyland-Jones B, Asmar L, et al. Randomized phase III study of trastuzumab, paclitaxel, and carboplatin compared with trastuzumab and paclitaxel in women with HER-2-overexpressing metastatic breast cancer. J Clin Oncol 2006; 24:2786-92.

11. National Comprehensive Cancer Network. NCCN clinical practice guidelines in oncology: breast cancer, version 1.2018. Available at: https://www.nccn.org/ professionals/physician_gls/default.aspx. Accessed: October 16, 2018.

12. Cardoso F, Costa A, Norton L, et al. 1st International consensus guidelines for advanced breast cancer (ABC 1). Breast 2012; 21:242-52.

13. Geyer CE, Forster J, Lindquist D, et al. Lapatinib plus capecitabine for HER2positive advanced breast cancer. N Engl J Med 2006; 355:2733-43.

14. Baselga J, Cortes J, Kim SB, et al. Pertuzumab plus trastuzumab plus docetaxel for metastatic breast cancer. N Engl J Med 2012; 366:109-19.

15. Tiwari SR, Mishra P, Abraham J. Neratinib, a novel HER2-targeted tyrosine kinase inhibitor. Clin Breast Cancer 2016; 16:344-8.

16. Swain SM, Baselga J, Kim SB, et al. Pertuzumab, trastuzumab, and docetaxel in HER2-positive metastatic breast cancer. N Engl J Med 2015; 372:724-34.

17. Toi M, Kashitani J, Tominaga T. Tumor angiogenesis is an independent prognostic indicator in primary breast carcinoma. Int J Cancer 1993; 55:371-4.

18. Weidner N, Semple JP, Welch WR, et al. Tumor angiogenesis and metastasiscorrelation in invasive breast carcinoma. $N$ Engl J Med 1991; 324:1-8.

19. Augustin HG, Koh GY, Thurston G, et al. Control of vascular morphogenesis and homeostasis through the angiopoietin-Tie system. Nat Rev Mol Cell Biol 2009; 10: $165-77$.

20. Folkman J. Role of angiogenesis in tumor growth and metastasis. Semin Oncol 2002; $29(6$ suppl 16):15-8.

21. Imanishi $\mathrm{Y}, \mathrm{Hu} \mathrm{B}$, Jarzynka MJ, et al. Angiopoietin-2 stimulates breast cancer metastasis through the alpha(5)beta(1) integrin-mediated pathway. Cancer Res 2007; 67:4254-63.

22. Li P, He Q, Luo C, et al. Diagnostic and prognostic potential of serum angiopoietin-2 expression in human breast cancer. Int J Clin Exp Pathol 2015; 8: 660-4.

23. Sfiligoi C, de Luca A, Cascone I, et al. Angiopoietin-2 expression in breast cancer correlates with lymph node invasion and short survival. Int J Cancer 2003; 103: 466-74.

24. Martin M, Makhson A, Gligorov J, et al. Phase II study of bevacizumab in combination with trastuzumab and capecitabine as first-line treatment for HER-2-positive locally recurrent or metastatic breast cancer. Oncologist 2012; 17:469-75.

25. Gianni L, Romieu GH, Lichinitser M, et al. AVEREL: a randomized phase III trial evaluating bevacizumab in combination with docetaxel and trastuzumab as firstline therapy for HER2-positive locally recurrent/metastatic breast cancer. J Clin Oncol 2013; 31:1719-25.

26. Carter WB, Ward MD. HER2 regulatory control of angiopoietin-2 in breast cancer. Surgery 2000; 128:153-8. 
27. Niu G, Carter WB. Human epidermal growth factor receptor 2 regulates angiopoietin-2 expression in breast cancer via AKT and mitogen-activated protein kinase pathways. Cancer Res 2007; 67:1487-93.

28. Coxon A, Bready J, Min H, et al. Context-dependent role of angiopoietin-1 inhibition in the suppression of angiogenesis and tumor growth: implications for AMG 386, an angiopoietin-1/2-neutralizing peptibody. Mol Cancer Ther 2010; 9: 2641-51.

29. Oliner J, Min H, Leal J, et al. Suppression of angiogenesis and tumor growth by selective inhibition of angiopoietin-2. Cancer Cell 2004; 6:507-16.

30. Herbst RS, Hong D, Chap L, et al. Safety, pharmacokinetics, and antitumor activity of AMG 386, a selective angiopoietin inhibitor, in adult patients with advanced solid tumors. I Clin Oncol 2009; 27:3557-65.

31. Hong DS, Gordon MS, Samlowski WE, et al. A phase I, open-label study of trebananib combined with sorafenib or sunitinib in patients with advanced rena cell carcinoma. Clin Genitourin Cancer 2014; 12:167-77.e162.

32. Hong DS, Kurzrock R, Mulay M, et al. A phase 1b, open-label study of trebananib plus bevacizumab or motesanib in patients with solid tumours. Oncotarget 2014; 5: 11154-67.

33. Rini B, Szczylik C, Tannir NM, et al. AMG 386 in combination with sorafenib in patients with metastatic clear cell carcinoma of the kidney: a randomized, doubleblind, placebo-controlled, phase 2 study. Cancer 2012; 118:6152-61.

34. Atkins MB, Gravis G, Drosik K, et al. Trebananib (AMG 386) in combination with sunitinib in patients with metastatic renal cell cancer: an open-label, multicenter, phase II study. J Clin Oncol 2015; 33:3431-8.

35. Mita AC, Takimoto CH, Mita M, et al. Phase 1 study of AMG 386, a selective angiopoietin 1/2-neutralizing peptibody, in combination with chemotherapy in adults with advanced solid tumors. Clin Cancer Res 2010; 16:3044-56.

36. Peeters M, Strickland AH, Lichinitser M, et al. A randomised, double-blind, placebo-controlled phase 2 study of trebananib (AMG 386) in combination with FOLFIRI in patients with previously treated metastatic colorectal carcinoma. Br J Cancer 2013; 108:503-11.

37. Karlan BY, Oza AM, Richardson GE, et al, Randomized, double-blind, placebocontrolled phase II study of AMG 386 combined with weekly paclitaxel in patients with recurrent ovarian cancer. J Clin Oncol 2012; 30:362-71.

38. Monk BJ, Poveda A, Vergote I, et al. Anti-angiopoietin therapy with trebananib for recurrent ovarian cancer (TRINOVA-1): a randomised, multicentre, double-blind, placebo-controlled phase 3 trial. Lancet Oncol 2014; 15:799-808.

39. Marth C, Vergote I, Scambia G, et al. ENGOT-ov-6/TRINOVA-2: randomized, double-blind, phase 3 study of pegylated liposomal doxorubicin plus trebananib or placebo in women with recurrent partially platinum-sensitive or resistant ovarian cancer. Eur J Cancer 2016; 70:111-21.

40. Vergote I, Scambia G, O'Malley DM, et al. Trinova-3/ENGOT-OV-2/GOG 3001: a randomized, double-blind phase 3 study of trebananib plus carboplatin paclitaxel as first-line treatment in advanced ovarian cancer. Int J Gynecol Cancer 2016; 26(suppl 3):13-4.

41. Dieras V, Wildiers H, Jassem J, et al. Trebananib (AMG 386) plus weekly paclitaxel with or without bevacizumab as first-line therapy for HER2-negative locally recurrent or metastatic breast cancer: a phase 2 randomized study. Breast 2015; 24:182-90.

42. Therasse P, Arbuck SG, Eisenhauer EA, et al. New guidelines to evaluate the response to treatment in solid tumors. European Organization for Research and Treatment of Cancer, National Cancer Institute of the United States, National Cancer Institute of Canada. J Natl Cancer Inst 2000; 92:205-16.
43. Cancer Therapy Evaluation Program. Common Terminology Criteria for Adverse Events v3.0 (CTCAE). Available at: http://ctep.cancer.gov/protocoldevelopment/ electronic_applications/docs/ctcaev3.pdf. Accessed: January 30, 2017.

44. Weeraratne DK, Lofgren J, Dinnogen S, et al. Development of a biosensor-based immunogenicity assay capable of blocking soluble drug target interference. I Immunol Methods 2013; 396:44-55.

45. Monk BJ, Minion L, Lambrechts S, et al. Incidence and management of edema associated with trebananib (AMG 386). Gynecol Oncol 2013; 130:636-41.

46. Eatock M, Tebbutt N, Bampton CL, et al. Phase II randomized, double-blind, placebo-controlled study of AMG 386 (trebananib) in combination with cisplatin and capecitabine in patients with metastatic gastro-oesophageal cancer. Ann Oncol 2013; 24:710-8.

47. Eskens FA, Verweij J. The clinical toxicity profile of vascular endothelial growth factor (VEGF) and vascular endothelial growth factor receptor (VEGFR) targeting angiogenesis inhibitors; a review. Eur J Cancer 2006; 42:3127-39.

48. Wu B, Johnson J, Soto M, et al. Investigation of the mechanism of clearance of AMG 386 , a selective angiopoietin-1/2 neutralizing peptibody, in splenectomized, nephrectomized, and FcRn knockout rodent models. Pharm Res 2012; 29:1057-65.

49. Suzuki T, Ishii-Watabe A, Tada M, et al. Importance of neonatal FcR in regulating the serum half-life of therapeutic proteins containing the Fc domain of human IgG1: a comparative study of the affinity of monoclonal antibodies and Fc-fusion proteins to human neonatal FcR. I Immunol 2010; 184:1968-76.

50. Taxol (paclitaxel). Full prescribing information. Princeton, NJ: Bristol-Myers Squibb Company; 2007.

51. Perjeta (pertuzumab). Full prescribing information. South San Francisco, CA: Genentech; 2017.

52. Perjeta (pertuzumab). Summary of product characteristics. Full prescribing information. South San Francisco: CAL Genentech; 2017.

53. Slamon DJ, Swain SM, Buyse M, et al. Primary results from BETH, a phase 3 controlled study of adjuvant chemotherapy and trastuzumab \pm bevacizumab in patients with HER2-positive, node-positive or high risk node-negative breast cancer. Cancer Res 2013; 73 (24 suppl), S1-03.

54. Pierga JY, Petit T, Delozier T, et al. Neoadjuvant bevacizumab, trastuzumab, and chemotherapy for primary inflammatory HER2-positive breast cancer (BEVERLY2): an open-label, single-arm phase 2 study. Lancet Oncol 2012; 13:375-84.

55. Yardley DA, Raefsky E, Castillo R, et al. Phase II study of neoadjuvant weekly nabpaclitaxel and carboplatin, with bevacizumab and trastuzumab, as treatment for women with locally advanced HER2 ${ }^{+}$breast cancer. Clin Breast Cancer 2011; 11 : 297-305.

56. Rugo HS, Chien AJ, Franco SX, et al. A phase II study of lapatinib and bevacizumab as treatment for HER2-overexpressing metastatic breast cancer. Breast Cancer Res Treat 2012; 134:13-20.

57. Argiris A, Kotsakis AP, Hoang T, et al. Cetuximab and bevacizumab: preclinical data and phase II trial in recurrent or metastatic squamous cell carcinoma of the head and neck. Ann Oncol 2013; 24:220-5.

58. Tournigand C, Chibaudel B, Samson B, et al. Bevacizumab with or without erlotinib as maintenance therapy in patients with metastatic colorectal cance (GERCOR DREAM; OPTIMOX3): a randomised, open-label, phase 3 trial. Lancet Oncol 2015; 16:1493-505.

59. Seto T, Kato T, Nishio M, et al. Erlotinib alone or with bevacizumab as first-line therapy in patients with advanced non-squamous non-small-cell lung cancer harbouring EGFR mutations (JO25567): an open-label, randomised, multicentre, phase 2 study. Lancet Oncol 2014; 15:1236-44. 